\title{
A METAFICÇÃO HISTORIOGRÁFICA EM MEMORIAL DO CONVENTO DE JOSÉ SARAMAGO
}

\section{THE HISTORIOGRAPHICAL METAFICTION IN MEMORIAL DO CONVENTO BY JOSÉ SARAMAGO}

\section{Raimundo Expeditos dos Santos Sousa}

Doutorando em Teoria da Literatura e Literatura Comparada pela Universidade Federal de Minas Gerais

E-mail: raimundo_sousa@terra.com.br

\section{Cristofane da Silveira Queiroz}

Licenciado em Letras pela Faculdade Saberes

Técnico em Assuntos educacionais na Universidade Federal de Minas Gerais

E-mail: cristq@hotmail.com

\section{RESUMO}

Memorial do Convento constitui uma importante reflexão sobre o passado histórico da sociedade portuguesa do século XVIII e seu impacto nos dias de hoje. Sabe-se que o autor, José Saramago, concebe a ficção a partir do registro da história. Desta forma, nas linhas que se seguem são evidenciados como o escritor trata a história no cerne da estética literária, resgatando-a criticamente e subvertendo-a, ou seja, lidando com a história de modo meta-ficcional numa obra exponencial da narrativa pós-moderna.

Palavras-chave: Pós-modernismo. José Saramago. Metaficção Historiográfica.

\begin{abstract}
Memorial do Convento is an important reflection on the history of Portuguese society of the eighteenth century and its impact today. It is known that the author, José Saramago, conceives fiction from the record of history. Thus, in the following lines it is highlighted how the writer treats the history at the heart of literary aesthetics, rescuing it critically and subverting it, that is, dealing with the history in a meta-fictional way in the exponential work of post-modern narrative.
\end{abstract}

Keywords: Postmodernism. José Saramago. Historiographical Metafiction. 


\section{INTRODUÇÃO}

A literatura produzida em Portugal é fruto das mudanças pelas quais passam aquele povo. A resistência à instauração do regime totalitário português em 1930, o denominado "Estado Novo", resultou numa literatura engajada, voltada para os problemas do país, trazendo, por exemplo, a escrita da denúncia contra a alienação. A revolução dos cravos de 1974, que derrubou esse regime, representou outro recente marco na literatura. Os escritores contemporâneos ensejaram a denúncia lúcida dos excessos cometidos pelo colonialismo português, a explicitação do universo feminino e, principalmente, o resgate ficcional da história passada e presente (ROANI, 2002).

É nesse contexto que se inscreve um dos mais brilhantes romancistas portugueses dos últimos tempos, José Saramago. Ensaísta, romancista e poeta, Saramago foi capaz de criar narrativas complexas, infligindo o cânone gramatical pela reinvenção da sintaxe e da pontuação, utilizando-se da linguagem alegórica, fazendo um resgate ficcional da história portuguesa, subvertendo-a, instaurando novas relações intertextuais e novas possibilidades do fazer literário. José Saramago publicou poemas, crônicas, contos, ensaios e romances, dentre os quais Levantado do Chão (1980), Memorial do Convento (1982), A jangada de Pedra (1986) e História do Cerco de Lisboa (1989) seguem a premissa da metaficção historiográfica e revelam o grande fascínio do autor pela interlocução entre literatura e história, através das malhas da ficção romanesca (ROANI, 2002).

Memorial do Convento, de 1982, obra pela qual José Saramago recebeu o Prêmio Nobel de Literatura em 1998, é objeto de análise desse artigo. Romance esse que recorre à história de Portugal, no período do reinado de Dom João V, no momento da construção do convento de Mafra, a guerra de sucessão pelo trono da Espanha e as perseguições da Santa Inquisição, e toma o referente histórico como premissa para a construção de uma obra fíctícia, multifacetada e plurissignificativa que tem, ao mesmo tempo, uma perspectiva histórica, social e individual.

O intuito desse trabalho consiste em verificar, através de um exercício de leitura, como o escritor trabalha a metaficção historiográfica, ou seja, como o autor instaura e posteriormente subverte os conceitos que almeja desafiar. Como, a partir do registro da história, o autor reinventa a realidade, analisando-a criticamente no cerne da estética, da linguagem literária, promovendo uma releitura crítica do passado histórico oficial. Paralelamente a esse exercício de leitura da referida obra Saramaguiana estão as questões inerentes à literatura pós-moderna, uma vez que a historiografia tem sido tema recorrente aos escritores atuais. Por isso faz-se necessária à contextualização do autor nessa tendência. 


\section{O ESTADO PÓS-MODERNO}

As últimas décadas do século XX têm sido caracterizadas por movimentos que romperam com tudo que, historicamente, tem sido crido como verdade fundamental. O pós-modernismo, seja ele na arte, na arquitetura ou na literatura instaura conceitos comumente acreditados como verdades para em seguida subvertê-los. A problemática do pós-modernismo está em seu próprio seio, em sua própria constituição. O pós-modernismo é, conforme Linda Hutcheon (1991, p. 04), "fundamentalmente contraditório, decididamente histórico e obrigatoriamente político".

\subsection{PÓS-MODERNIDADE E HISTÓRIA}

O mundo histórico constitui um entrave para o pensamento pós-moderno, por isso este se tornou alvo de releitura e reescrita. Para instaurar os conceitos a que se deseja subverter, parodia os elementos advindos do mundo histórico, problematizando-os, para se compreender o presente. “ $\mathrm{O}$ pós-modernismo ensina que todas as práticas culturais têm um subtexto ideológico que determina as condições da própria possibilidade de sua produção ou de seu sentido" (HUTCHEON, 1991, p. 122).

O próprio pensamento histórico passa pelas transformações influenciadas pelo pensamento pós-moderno. Com a Nova História, não só a veracidade dos referentes históricos tem sido contestada, como também se tem buscado deslocar o olhar que conta a história do alto, do ponto de vista de quem exerce o poder, para a ótica do subalterno, do subjugado por esse mesmo poder. Com isso, a nova história encarrega-se de recontar o historicamente registrado, revisitando todo o nosso passado conhecido. A história científica de Ranke, que rompeu com a literatura no século XIX, passa a ser contestada a partir do preceito de que não é isenta de subjetividade. Antes de Ranke a literatura e a história eram consideradas como ramos da mesma árvore do saber, uma árvore que buscava interpretar a experiência, com o objetivo de orientar e elevar o homem (HUTCHEON, 1991). No pós-modernismo "parece haver um novo desejo de pensar historicamente e, hoje, pensar historicamente é pensar crítica e contextualmente" (HUTCHEON, 1991, p. 121).

O movimento modernista instaurou novas perspectivas na arte a partir do desejo de constituição do novo. Assim, sua recorrência a história, quando ocorria, "tinha objetivo de desenvolver sua 'presentitude' [sic] ou permitir sua transcendência” (HUTCHEON, 1991, p. 121). Já no pós-modernismo a história passa a ser enfrentada enquanto discurso, uma vez que foi nesse 
período que a escrita da história passou a ser reconhecida como discurso, que como tal é imbuído de ideologia. A produção do fato histórico então passa a ser vista como passível de parcialidade e subjetividade. Linda Hutcheon afirmou que: "O que a escrita pós-moderna da história e da literatura nos ensinou é que a ficção e a história são discursos, que ambas constituem sistemas de significação pelos quais damos sentido ao passado" (HUTCHEON, 1991, p. 122),

Não se fez com que a história ficasse obsoleta: no entanto, ela está sendo repensada como uma criação humana. E, ao afirmar que a história não existe a não ser como texto, o pós-modernismo não nega, estúpida e 'euforicamente', que o passado existiu, mas apenas afirma que agora, para nós, seu acesso está totalmente condicionado pela textualidade. (HUTCHEON, 1991, p. 34).

O escritor inglês Oscar Wilde, no final do século XIX, em uma de suas célebres citações disse: "A única coisa que devemos a história é a tarefa de reescrevê-la". O pós-modernismo trouxe a reescrita da história, mas com qual objetivo? "O pós-modernismo volta a confrontar a natureza problemática do passado como objeto de conhecimento para nós no presente" (HUTCHEON, 1991, p. 126). Então essa revista à história registrada objetiva evidenciar aquilo que a história formal preferiu ignorar, “o que está sendo contestado pelo pós-modernismo são os princípios de nossa ideologia dominante" (HUTCHEON, 1991, p. 15). Assim, esse retorno se caracteriza por um desejo de reelaboração crítica.

\subsection{PÓS-MODERNIDADE E LITERATURA}

A literatura, assim como a história, é reconhecida como discurso. Discurso polissêmico, atravessado por outros discursos e como tal, passível de ideologias. A renovação do discurso histórico, como vimos antes, ocorre paralelamente a um novo interesse pela história que se manifesta há algumas décadas na literatura mundial e que tem sido apontado como um traço ou característica marcadamente pós-moderna.

A literatura pós-moderna abusa das convenções do discurso e de sua constituição paradoxal, aliada a um projeto de crítica de velhos temas. Conforme Roland Barthes (1978), a literatura é meio para trapacear a língua. Os escritores pós-modernos assimilaram esse poder presente na linguagem de uma forma tão evidente como não há preceitos. É certo que conhecemos escritos de grande contestação social ou política, além da crítica de costumes e das mazelas humanas, todos se utilizando das metáforas, comparações, ironias e jogos de sentido. No entanto, foi na pós-modernidade que a literatura engendrou um uso programático da narração trazendo a problemática da história tratada com uma liberdade nunca antes conhecida no âmbito da ficção. 
Evidencia-se o conflito entre história e literatura. Os estudos pós-modernos problematizam a narrativa histórica, questionam o quanto ela se distancia da escrita literária e se tal distanciamento realmente existe. Diz Umberto Eco (1991) sobre o assunto: "A resposta pós-moderna ao moderno consiste em reconhecer que o passado, como não pode ser realmente destruído porque sua destruição conduz ao silêncio [a descoberto do modernismo], precisa ser reavaliado: mas com ironia, e não com inocência." (apud HUTCHEON, 1991, p. 67). E é isso que a metaficção historiográfica faz, retoma temas históricos e brinca com as verdades históricas.

A metaficção historiográfica adota uma ideologia pós-moderna de pluralidade e reconhecimento da diferença; o 'tipo' tem poucas funções, exceto como algo a ser atacado com ironia (HUTCHEON, 1991, p.150). Com isso a pós-modernidade na literatura traz as novas possibilidades do fazer literário. Assim, além da dicotomia entre História e Literatura, permite aos autores a quebra de outras barreiras e paradoxos, apagando os limites entre as culturas erudita e de massa com o objetivo de revisão crítica e "infringindo" o cânone gramatical e sintático, por exemplo.

Para chegar a essas formas de questionamento, a escrita contemporânea lança mão de uma nova estética, que traz um novo modelo. O pós-modernismo é contra os modelos, e cria um modelo 'contramodelo', levando à ideia de obra aberta, como proposta de um campo de possibilidades interpretativas, como configuração de estímulos dotados de uma substancial indeterminação, de maneira a induzir o fruidor a uma série de leituras sempre variáveis. Temos, enfim, uma estrutura, que se assemelha a uma 'constelação' de elementos que se prestam a diversas relações recíprocas. (Eco, apud HUTCHEON, 1991, p.76).

\section{JOSÉ SARAMAGO E A ESCRITURA PÓS-MODERNA}

Como expresso anteriormente, o pensamento pós-moderno está na subversão ou autorreflexão daquilo que se deseja modificar. A arte pós-moderna é modificadora, já que almeja estágios mais elevados de consciência e absorção do mundo atual.

Homem político, filiado ao partido comunista português, José Saramago é um propagador do pensamento pós-moderno e sua linguagem contêm toda a autorreflexividade inerente a esse movimento que só agora começa a ser teorizado. Saramago é fruto das recentes mudanças políticas pelas quais passou Portugal no século XX e fez de seus escritos o meio para alcançar essa lucidez. Foi o regime totalitário português que o fez ser despedido do Diário de Notícias e foi então que ele se dedicou somente à literatura. 
A subversão na escrita é uma das marcas desse autor, que consegue criar um ritmo de escrita que lembra a poesia, reconstituindo a oralidade e a coloquialidade em seus escritos, utilizando a comparação e a metáfora, além de provérbios e ditos populares. Há a recriação do uso da pontuação, a construção de efeitos irônicos e humorísticos e entrelaçamento do seu discurso com outros discursos literários (como o de Camões) e jogos de conceitos típicos do Barroco.

Vemos que as questões de linguagem propriamente pós-modernas são colocadas e podem chocar o leitor logo nas primeiras páginas. Existem poucos pontos finais, a maioria da pontuação é feita por vírgulas, e há o uso, algumas vezes, de letra maiúscula mesmo sem que a sentença seja iniciada por nomes próprios. Fica claro que o autor não pretende seguir um padrão gramatical de pontuação, e a ausência de padronização pode causar uma confusão no leitor que, em alguns momentos, não sabe que caminho seguir. Essa construção aliada a outros fatores cria mais rotas de interpretação, formulando um discurso aberto que é um chamado à responsabilidade, à escolha individual, é um desafio e um estímulo à imaginação. Como notado no fragmento de Memorial de Convento abaixo:

Perguntou el-rei, É verdade o que acaba de dizer-me sua eminência, que se eu prometer levantar um convento em Mafra terei filhos, e o frade respondeu, Verdade é, senhor, porém só se o convento for franciscano, [...] (SARAMAGO, 2005, p. 14).

Outro aspecto, a cultura popular, é muito recorrente na obra saramaguiana. O homem comum é retratado em seus romances, até mesmo como agente recriador da história. Memorial do Convento poderia se chamar "Memorial daqueles que construíram o convento", já que a narração traz à tona, entre muitas outras relações, a saga dos milhões de trabalhadores que edificaram aquela magnífica obra.

O narrador Saramaguiano apresenta uma natureza múltipla. As suas vozes são facilmente confundidas com a voz das personagens e o narrador mostra-se ainda capaz de estabelecer relações de ironia e de humor com os acontecimentos narrados. O narrador assume o papel de comentador e de crítico não se distanciando de uma relação de cumplicidade com o fato narrado. O narrador Saramaguiano induz à reflexão.

Saramago tem em mente colocar em contato e em confronto o ser e o tempo. Na verdade, o autor realiza um movimento inverso àquele que é típico do romance histórico: em vez de levar o presente até ao passado, reconstituindo-o fielmente, invoca o passado com estratégias discursivas peculiares suportadas frequentemente pela ironia de modo a conseguir atingir a memória com um olhar do presente. 
As personagens são alvo da análise objetiva até à exposição do estatuto fíctício e de inverosimilhança numa mistura de realista e ficcional, que é apresentada ao leitor revelando a metaficção historiográfica. Em Memorial do Convento a personagem é excêntrica e singular. Destaca-se pelo insólito e pela diferença, como Baltasar e Blimunda, o soldado maneta e a mulher que tinha poderes. Por outro lado, o coletivo dos trabalhadores de Mafra, esquecidos num romance histórico tradicional, são elevados pela diferença ao centro das atenções na narrativa, numa nítida intenção de valorização. A subversão é transgressão na forma de tratamento das personagens Baltasar e Blimunda que assumem, no fundo, o centro do romance, representando o povo e o trabalho, juntamente com os reais construtores do convento ao contrário do que o leitor poderia esperar a partir das páginas iniciais, nas quais Mafra e o casal real se perfilam como núcleo da narrativa.

A subversão conhece o seu grau mais elevado no tratamento das grandes figuras históricas. Em Saramago essas figuras históricas perdem a sua grandeza histórica e são pintadas com as cores da caricatura. São exemplos máximos o rei e a rainha, meros instrumentos da necessidade nacional em produzir um herdeiro: $O$ cântaro está à espera da fonte: "[...] fique ela sabendo que seu marido vem aí. Que espere. Por enquanto, ainda el-rei está a preparar-se para a noite" (SARAMAGO, 2005, p.13).

Há quem classifique Saramago como neorrealista, como afirmou António J. Saraiva (1999, p. 168), “[...] José Saramago é um escritor contemporâneo dos Neorrealistas e tenta dar credibilidade à doutrina de que os Neorrealistas eram porta-vozes". No entanto, a sua análise da sociedade transcende as denúncias, Saramago destaca a constituição ideológica presente da reinvenção da história, partindo da análise sobre as relações entre a história passada e presente, ou seja, não é o passado que é discutido, mas sim o presente, o passado é apenas um referente alegórico sobre o qual Saramago fundamenta sua crítica.

Em suas obras, Saramago fixa momentos cruciais da história lusitana. Seu romance deixa de ser apenas o retrato de uma época ou uma mera crônica social, para se tornar ação. Seu objetivo não é distrair o público, mas sim agir sobre ele, provocando polêmica, reflexão e visão crítica da história portuguesa (ROANI, 2002, p. 17).

Fala-se hoje de Neorromantismo, Neobarroco e Neorrealismo. No entanto, na pós-modernidade, a recorrência ao que fora produzido subjaz ao mero resgate com nuances contemporâneas do passado. Evidentemente as questões enfrentadas em Portugal no último século fizeram com que o levantamento crítico dos hábitos sociais e políticos daquele povo fosse levantado, aproximando-se da literatura experimentada através da análise científica da sociedade durante o Realismo. Como ressaltaram Abdala Jr. \& Paschoalin (1982, p. 157): 
A eclosão do movimento neorrealista esteve associada à resistência antifascista ao final da década de 1930. Colocou-se a nova tendência literária contra o 'descompromisso' do movimento anterior, o Presencismo, e defendia uma literatura 'engajada', voltada para os problemas concretos do país. A literatura deveria contribuir para a conscientização do público-leitor e para caracterizar os problemas da estrutura política, econômica e social da sociedade portuguesa.

Vale ressaltar que para a teoria da literatura o Neorrealismo está incluindo na gênese do chamado pós-modernismo, como nas publicações de Adbala Jr. \& Paschoalim e José António Saraiva. Linda Hutcheon, no entanto, perfaz essa divisão a partir da poética pós-moderna por ela levantada e introduz que a característica maior do pós-modernismo é a chamada Metaficção

Historiográfica, ou seja, a narrativa dotada de autorreflexividade paródica, conforme exposto na seção seguinte.

José Saramago produziu seus escritos segundo o estatuto pós-moderno de reelaboração crítica e foi muito além do mero levantamento da problemática social. O autor explora a construção e a reinvenção da identidade nacional por meio da manipulação e da supressão de dados tantos históricos quanto mitológicos. Ao demonstrar que a verdade absoluta sobre o passado é inacessível, o escritor se inscreve então, no pós-modernismo.

\section{A HISTÓRIA NA LITERATURA EM MEMORIAL DO CONVENTO}

Memorial do Convento se passa no século XVIII, à época do Reinado de Dom João V, da guerra de sucessão do trono espanhol e as perseguições da santa inquisição. A história na literatura em Memorial do Convento é a responsável pela contextualização do romance, uma vez que todo romance de funda em tempo, espaço, enredo, narrador e personagens. Ela é também um elemento imagético e subversivo. A história nessa obra fictícia não é resgatada somente para ser narrada, não se pretende criar um universo romântico e idealizado daquele passado histórico, antes, é pelo combate a essa idealização que a história é resgatada.

A fronteira entre Ficção e História é problematizada e questionada, por isso há personagens provenientes dos anais da história, a saber: O rei de Portugal, Dom João V; a rainha Dona Maria Josefa, princesa Austríaca casada com o rei de Portugal; o padre brasileiro Bartolomeu Lourenço de Gusmão, considerado o pai da aviação, antecessor de Dumont; e o músico italiano especialista em cravo, Domenico Scarlatti. No entanto, esses personagens históricos são revisitados e reelaborados criticamente, ou seja, é um olhar diferente do meramente historiográfico. Há também grande destaque para os personagens fictícios, que representam justamente aqueles esquecidos pela história, ou são meio para as digressões do autor. 
A subversão da história começa já nas primeiras linhas do romance, ao qual a posição canônica ocupada pelos reis é dessacralizada e transformada em caricatura, como já observado.

D. João, quinto do nome na tabela real, irá esta noite ao quarto de sua mulher, dona Maria Ana Josefa, que chegou há mais de dois anos da Áustria para dar infantes à coroa portuguesa e até hoje não emprenhou. Já se murmura na corte, dentro e fora do palácio, que a rainha, provavelmente, tem a madre seca, insinuação muito resguardada de orelhas e bocas delatoras e que só entre íntimos se confia. Quer caiba a culpa ao rei, nem pensar, primeiro porque a esterilidade não é mal dos homens, das mulheres sim, por isso são repudiadas tantas vezes, e segundo, material prova, se necessária ela fosse, porque abundam no reino bastardos da real semente e ainda agora a procissão vai na praça (SARAMAGO, 2005, p. 11).

Essa passagem é fundada em um tom irônico e prosaico que acompanhará toda a narração da nobreza e do clero ao longo de todo o romance. A infertilidade da rainha é que desencadeará a construção do convento, como veremos a seguir. As tentativas do rei para que Dona Maria Josefa engravide são tratadas com frieza a partir da premissa de que são meros objetos da necessidade nacional de se fazer herdeiros. O próprio coito é tratado de forma cerimoniosa em que há, por exemplo, muitas vestes e a participação de inúmeros criados:

[...] fique ela sabendo que seu marido vem aí. Que espere. Por enquanto, ainda el-rei está a preparar-se para a noite. Despiram-no os camaristas, vestiram-no com o trajo da função e do estilo, passadas as roupas de mão em mão tão reverentemente como relíquias de santas que tivessem trespassado donzelas, e isto se passa na presença de outros criados e pajens [...] Enfim, de tanto se esforçarem todos ficou preparado el-rei [...] já não tarda um minuto que D. João $\mathrm{V}$ se encaminhe ao quarto da rainha. $\mathrm{O}$ cântaro está à espera da fonte. (SARAMAGO, 2005, p. 13)

D. Maria Ana é retratada como uma rainha triste e medrosa, muito apegada à religião. D. Maria vive um casamento de aparências, em que as regras e formalidades se estendem ao leito conjugal, fazendo do ato de amor com o rei um encontro frio, programado e indiferente em que a ela não é dada nenhuma oportunidade de gozo:

\footnotetext{
Mas nem a persistência do rei, que, salvo dificultação canônica ou impedimento fisiológico, duas vezes por semana cumpre vigorosamente o seu dever real e conjugal, nem a paciência e humildade da rainha que, a mais das preces, se sacrifica a uma imobilidade total depois de retirar-se de si e da cama o esposo, para que se não perturbem em seu gerativo acomodamento os líquidos comuns, escassos os seus por falta de estímulo e tempo [...]. (SARAMAGO, 2005, p. 11)
}

Essa passagem não é retratada pela história tradicional. Há então uma desconstrução do relato histórico pelo tom de pastiche, ironia e com termos indignos à história: A rainha enrolada em seu lençol de penas de ganso enroscada como topeira e recozendo a cheiros e secreções.

O Rei D. João V, historicamente, é conhecido com o "rei construtor" devido às obras engendradas em seu reinado, como por exemplo, o convento de Mafra e o Mosteiro da Batalha. 
Em Memorial do Convento, o narrador faz uma descrição metódica da montagem da miniatura da Basílica de São Pedro de Roma pelo rei D. João, que no texto, tem uma função metonímica parodicamente invertida, ou seja, tido pelos historiadores oficiais como o rei que construiu o convento de Mafra, o narrador esforça-se para demonstrar que o único monastério que D. João $\mathrm{V}$ foi capaz de erigir foi à miniatura da basílica, dispersa em pedaços de encaixar, pelo antigo sistema de macho e fêmea, como observa o narrador e quase tão grande como deus, como observa o próprio rei no texto.

É sabido que o clero aproximou-se muito da nobreza na Idade Média e esteve atrelado a esta durante muitos séculos. À época de D. João V, como nos mostra a história, o clero circulava livremente pelo palácio real e, como nos mostra o romance, tiravam proveito dessa aproximação tomando para si o poder, de forma a influenciar ou até mesmo decidir pelo rei. O clero em Memorial do Convento é narrado como corrupto e mentiroso. Os Franciscanos, por sua vez, aproveitaram da situação do rei, que se encontrava há três anos tentando engravidar a rainha e obter sucessão, para conseguir o seu consenso quanto à construção de um convento na vila de Mafra.

\begin{abstract}
Mas vem agora entrando D. Nuno da Cunha, que é bispo inquisidor, e traz consigo um franciscano velho. [...] Aquele que além está é frei António de S. José, a quem falando-lhe eu sobre a tristeza de vossa majestade por não lhe dar filhos a rainha nossa senhora, pedi que encomendasse vossa majestade a Deus para que lhe desse sucessão, [...]

Perguntou el-rei. É verdade o que acaba de dizer-me Sua Eminência, que se eu prometer levantar um convento em Mafra terei filhos, e o frade respondeu, Verdade é, senhor porém só se o convento for franciscano, e tornou el-rei, Como sabeis, e frei António disse, Sei, não sei como vim a saber, eu sou apenas a boca de que a verdade se serve para falar, a fé não tem mais que responder, construa Vossa Majestade o convento e terá brevemente sucessão, não o construa e Deus decidirá. (SARAMAGO, 2005, p. 13-14)
\end{abstract}

E assim se deu a promessa do rei de construir um convento franciscano em Mafra. Uma construção tão grandiosa que merece um Memorial, fruto de uma sociedade regida à luz da hipocrisia, de um rei absolutista e com um clero usurpador com objetivo único de satisfazer suas próprias vaidades. Como observou Perrone-Moisés (1999, p. 103):

O colosso arquitetônico aparece claramente como expressão e produto de um dado absolutismo monárquico, de uma dada sociedade exteriormente pomposa, magnificente ou megalômana, e interiormente corroída de franquezas, conflitos, hipocrisias, vícios ou podridões e assente na faraônica exploração e coacção da grande maioria.

A partir daqui, a história registra apenas os anos levados para conclusão da grandiosa obra, mas nenhum trabalhador, ou o próprio coletivo de trabalhadores é sequer citado. Assim no ambiente palaciano as relações são recontadas de forma diferente aquelas já conhecidas, dentro da ironia e paródia do narrador. 
O padre brasileiro Bartolomeu Lourenço de Gusmão (1685-1724), jesuíta, é também personagem desse memorial do trabalho. O padre tinha o desejo de voar e contou com a autorização do rei para seu invento. No entanto, enquanto Padre jesuíta, vivendo dentro dos parâmetros da inquisição, outro referente histórico dessa obra, teve seu trabalho desenvolvido na clandestinidade. Nos anais da História, a fama do Padre Bartolomeu Gusmão decorre dos sermões que pregava, dos conhecimentos de humanidades e teologia, mas, acima de tudo, de ter testado um aparelho aerostático de sua invenção, denominado "passarola".

Com perdão da confiança, só os pássaros voam, e os anjos, e os homens quando sonham, mas em sonhos não há firmeza, Não tens vivido em Lisboa, nunca te vi, Estive na guerra quatro anos e a minha terra é Mafra, Pois eu faz dois anos que voei, primeiro fiz um balão que ardeu, depois construí outro que subiu até ao teto duma sala do paço, enfim outro que saiu por uma janela da Casa da Índia e ninguém tornou a ver, Mas voou em pessoa, ou só voaram os balões, foi o mesmo que ter voado eu (SARAMAGO, 2005, p. 60).

Pelo dado histórico, o engenho de Gusmão, após duas tentativas de voo mal sucedidas, teria conseguido elevar-se a quatro metros de altura. Em Memorial do Convento, o padre conseguiu voar a passarola no alto dos céus por mais de uma vez e numa delas sobrevoou o convento de Mafra, chegando a ser confundida com o Espírito Santo.

Em um episódio, D. João manda que venha da Itália o maestro barroco Domênico Scarlatti para dar lições de música a sua filha. Scarlatti esteve realmente em Portugal para ensinar lições de cravo à infanta Maria Bárbara, primeira filha do rei, dos cinco que viria a ter, como observou o narrador: o rei terá que se contentar com uma menina.

Outro referente histórico é a guerra de sucessão do trono espanhol, que foi, acima de tudo, uma guerra mercantilista entre potências econômicas pela primazia comercial nas colônias ultramarinas. A ausência de herdeiros detonou a guerra em 1704 que durou oito anos. De um lado a Inglaterra, a Holanda, a Alemanha e Portugal, apoiando o arquiduque Carlos, filho do imperador Leopoldo da Alemanha; do outro, os franceses e os espanhóis que tinham a garantia legal de um testamento que dava a Felipe, neto de Luís XIV, o trono vago (SARAIVA, 1996). Foi nessa guerra de Baltazar Mateus, que o sete-sóis, personagem fictício, perdeu a mão:

Este que por desafrontada aparência, sacudir da espada e desparelhadas vestes, ainda que descalço, parece soldado, é Baltasar Mateus, o Sete-Sóis. Foi mandado embora do exército por já não ter serventia nele, depois de lhe cortarem a mão esquerda pelo nó do pulso, estraçalhada por uma bala em frente de Jerez de los Caballeros [...] Sete-Sóis, mutilado, caminhava para Lisboa pela estrada real, credor de uma mão esquerda que ficara parte em Espanha e parte em Portugal, por artes de uma guerra em que se haveria de decidir quem viria a sentar-se no trono de Espanha, se um Carlos austríaco ou um Filipe Francês, português nenhum [...] (SARAMAGO, 2005, p. 34- 35). 
Nesse fragmento, vemos como o narrador retrata a inutilidade dessa guerra para Portugal. Portugal é até hoje um país católico e que conserva os dogmas aos moldes de como ocorriam anos atrás: as procissões, as penitências, o pagamento de promessas ainda são comuns. No século XVIII, os autos-de-fé tinham um papel muito importante para o controle da Igreja sobre o povo, seu objetivo não era reconciliar o pecador com Deus, mas manter acesa a chama do seu crime através da humilhação pública e o confisco dos bens, da aplicação de penas como o açoite até a prisão perpétua e o degredo, o garrote e a fogueira.

Para o narrador de Memorial do Convento:

Agora é tempo de pagar os cometidos excessos, mortificar a alma para que o corpo finja arrepender-se, ele rebelde, ele insurrecto, este corpo parco e porco da pocilga que é Lisboa. [...].

Vai sair à procissão de penitência. Castigamos a carne pelo jejum, maceremo-la agora pelo açoite. Comendo pouco purificam-se os humores, sofrendo alguma coisa escovam-se as costuras da alma.( SARAMAGO, 2005, p. 28)

Paralelamente as festas religiosas davam vazão aos desejos recalcados do povo, promovendo uma euforia coletiva. Aqueles eram uns dos poucos momentos em que as diferenças sociais deixavam de ser importantes. Disso o narrador se dá conta ao se referir à Quaresma: "Mas esta cidade, mais que todas, é uma boca que mastiga de sobejo para um lado e de escasso para o outro, não havendo, portanto mediano termo [...] Porém, a Quaresma, como o sol, quando nasce, é para todos." (SARAMAGO, 2005, p. 25).

É através da descrição das festas religiosas que o narrador relata a hipocrisia, a luxúria e a libertinagem na qual o clero secular e regular vivia em Portugal. A Santa Inquisição, outro referente histórico em Memorial do Convento foi instalada em Portugal a pedido de D. João III, sob a alegação de que os judeus ameaçavam a fé cristã (SARAIVA, 1996). Obviamente, havia o interesse do rei em aumentar os bens da coroa através dos bens confiscados aos judeus condenados. Conforme Saraiva (1996, p. 182):

Em 1531, D. João III pediu ao papa a licença necessária para a organização da Inquisição em Portugal. Os cristãos-novos mobilizaram toda a sua força económica para o impedir, afirmando que o que se pretendia era apenas espoliá-los. Existe muita documentação sobre essa luta diplomática e a sua leitura obriga a dar razão aos Judeus: a questão do confisco das fortunas teve papel fundamental.

As perseguições da santa inquisição fecham o romance, quando Baltazar é condenado à fogueira:

São onze os supliciados. A queima já vai adiantada, os rostos mal se distinguem. Naquele extremo arde um homem a quem falta a mão esquerda. Talvez por ter a barba enegrecida, prodígio cosmético da fuligem, parece mais novo. E uma nuvem fechada está no centro do seu corpo. Então Blimunda disse, Vem. Desprendeu-se a vontade de Baltazar Sete-Sóis, mas não subiu para as estrelas, se à terra pertencia e a Blimunda (SARAMAGO, 2005, p. 347). 
Memorial do Convento é fundado na História e é a partir dela que se á a constituição dos personagens fictícios em um universo entrecruzado ao histórico, são exemplos deles os trabalhadores do convento, recrutados de forma cruel:

Deve-se a construção do convento de Mafra ao rei D.João V, por um voto que fez se lhe nascesse um filho, vão aqui seiscentos homens que não fizeram filho nenhum à rainha $\mathrm{e}$ eles é que pagam o voto, que se lixam, com o perdão da anacrônica voz. (SARAMAGO, 2005, p. 224)

[...] em todos os lugares aonde pôde chegar a justiça de Sua Majestade, os homens, atados como reses, folgados apenas quanto bastasse para não se atropelarem, viam as mulheres e os filhos implorando o corregedor, procurando subornar os quadrilheiros com alguns ovos, uma galinha, míseros expedientes que de nada serviam, pois a moeda com que el-rei de Portugal cobra os seus tributos é o ouro, é a esmeralda, é o diamante, é a pimenta, a canela, é o marfim e o tabaco, é o açúcar e a sucupira, lágrimas não correm na alfândega.( SARAMAGO, 2005, p. 254)

João Roberto Maia, em seu excelente artigo: Memorial do Convento: "falar das mãos, falar das obras" (2004), ressalta o objetivo na exposição da questão do trabalho em Memorial do

\section{Convento:}

Nesse romance de José Saramago, a recriação ficcional de um fato histórico, a edificação do convento de Mafra, tem como dois de seus principais móveis, evidentemente complementares, a certeza de que a grandiosidade da obra só deve ser reconhecida pela dimensão do sacrifício que custou àqueles que, por necessidade ou mesmo à força, foram os verdadeiros construtores, e o propósito de desabonar o monumento histórico como algo favorável à boa reputação dos poderosos, para dessoterrar seu conteúdo humano e social, que se concretiza no exercício do trabalho anônimo tal qual se representa no romance.

Nos termos do narrador, trata-se de "não consentir que esqueçamos o que [...] se costuma olhar sem mais consideração, para não ficar oculto aquele que faz sob aquilo que é feito". Sendo assim, é o mundo do trabalho que interessa destacar, o foco tem de estar na experiência dos homens que trabalham - os quais "se os quisermos ver, tem de ser mais de perto" (SARAMAGO, 2005, p. 280-281), diz o narrador, dando expressão lapidar à tarefa de que se incumbe. O narrador dá voz a esses 20 (vinte) mil trabalhadores, como ele mesmo ressalta:

O sino da igreja de Santo André, no fundo do vale, deu as trindades. Por sobre a Ilha da Madeira, nas ruas e terreiros, dentro das tabernas e casas de acomodação, ouve-se um murmúrio contínuo, como o do mar ao longe. Estariam vinte mil homens dizendo a oração da tarde, estariam contando uns aos outros as suas vidas, vá lá averiguar-se. (SARAMAGO, 2005, p. 238)

Alguns deles contam, em primeira pessoa, a sua história de família, destino e expectativas e cada um deles é narrador em foco cambiante.

O meu nome é Francisco Marques, nasci em Cheleiros, que é aqui perto de Mafra, umas duas léguas [...] O meu nome é João pequeno, não tenho pai [...] Chamo-me Joaquim da Rocha, nasci no termo do Pombal [...] O meu nome é Manuel Milho, venho dos campos de Santarém [...] O meu nome é João Anes, vim do Porto e sou tanoeiro [...] O meu nome é Julião Mau-Tempo, sou natural do Alentejo [...]. (SARAMAGO, 2005, p. 238 - 291) 
Por último, Memorial do Convento tem em seus personagens Baltazar Mateus, o Sete-Sóis, e Blimunda seus pontos altos, seus protagonistas, representantes do povo, daqueles sem prestígio, mesmo assim, dotados de força, como é Baltazar e, de poderes, como é Blimunda.

\begin{abstract}
Baltasar Mateus, o Sete-Sóis, está calado, apenas olha fixamente Blimunda, e de cada vez que ela o olha a ele sente um aperto na boca do estômago, porque olhos como estes nunca se viram, claros de cinzento, ou verde, ou azul, que com a luz de fora variam ou o pensamento de dentro, $\mathrm{e}$ às vezes tornam-se negros noturnos ou brancos brilhantes como lasca de carvão de pedra. [...] mas agora só tem olhos para os olhos de Blimunda, ou para o corpo dela, que é alto e delgado como a inglesa que acordado sonhou no preciso dia em que desembarcou em Lisboa. (SARAMAGO, 2005, p. 48)
\end{abstract}

É através desses personagens a autorreflexividade do romance é constituída, ou seja, pela instauração do cânone sua posterior subversão. Enquanto o casamento do rei é uma conveniência monárquica, a união de Baltasar e Blimunda é regida pelo amor e pela paixão:

Entraram no quintal. O luar já era cor de leite. [...] Havia ali uma velha barraca coberta de
bunho apodrecido [...] para dentro da barraca o levou Blimunda [...] só Gabriel aqui virá
ter encontros depois de mudadas estas vidas, tão perto isso já vem e ninguém o adivinha.
Talvez alguém, talvez Blimunda, não por ter puxado Baltasar para a barraca, $[. .$.$] mas por$
uma ânsia que lhe aperta o coração, pela violência com que abraça Baltasar, pela
sofreguidão do beijo, pobres bocas, perdida está a frescura, perdidos estão alguns dentes,
partidos outros, afinal o amor existe sobre todas as coisas. (SARAMAGO, 2005, p. 331)

E assim, esses dois personagens intrinsecamente fictícios vão deflagrando a outra história, a dos esquecidos pela história oficial e, através dessa transgressão aos cânones, o narrador evidencia sua denúncia. O olhar de Blimunda é a alegoria criada para falar da visão de um mundo corrompido pelos desmandos e a ganância dos que detêm o poder. Baltasar retrata a força do trabalho braçal. Nos piolhos que Blimunda cata nos cabelos de Baltasar, na sujeira e no lixo do Entrudo, nos cães leprosos, nos percevejos e no mau cheiro de Lisboa, há mais que o retrato não poético de uma época; há o lodo da estratificação social e seus valores de aparência. Por fim, a proposta de escrever um memorial do convento, é a de fazer um memorial dos verdadeiros construtores do convento, com toda a sua pobreza, fruto dos governos autoritários que não se interessam em instaurar políticas econômicas de minimização das diferenças sociais.

\title{
5 MEMORIAL DO CONVENTO - ROMANCE HISTÓRICO OU METAFICÇÃO HISTORIOGRÁFICA?
}

Uma obra tão distinta quanto Memorial de Convento é passível de questionamentos e interrogações. A própria crítica literária encontra insuficiência de critérios para classificar as obras do autor. A quem intitule Memorial do Convento como um romance histórico, outros como 
Metaficção Historiográfica, dada a sua autorreflexividade, presente não na superfície do texto, mas em todas as entrelinhas do discurso escrito na obra. Os romances históricos, surgidos no início do século XIX, são caracterizados pela reconstrução, com enredo fictício, dos costumes, fala e instituições do passado, com uma mistura de personagens históricos e de ficção. Neste romance, específico, a prosa narrativa ficcional decorre no passado.

A literatura, cuja ação decorre num passado histórico sempre foi abundante, mas, no ocidente, Walter Scott iniciou a tradição moderna ao situar romances de amor num passado que tem como base fatos reconhecidos. O uso que este autor fez dos pormenores históricos e as subsequentes imitações que escritores europeus desenvolveram da sua técnica levaram a que o gênero prosperasse (JAMESON, 2007). No entanto, o universo prosódico desse gênero, limita-se à recriação do plano histórico, com nuances românticas e neoclássicas, no qual o universo passado perfeito é reiterado de forma nostálgica, nunca com o intuito subversivo e nunca provido de crítica.

Já a Metaficção Historiográfica caracteriza-se pela autorreflexividade quanto ao referente que se propõe a expor. Assim, o passado na Metaficção Historiográfica segue um caminho diferente do da historiografia. Em Memorial do Convento, ele é resgatado para ser compreendido pela vertente da atualização ideológica. Como Hutcheon (1991) afirma, a Metaficção Historiográfica instaura, para posteriormente subverter, os conceitos que desafia, ela tem a vantagem de salientar os dois aspectos fundamentais desta ficção: por um lado o seu caráter metadiscursivo e, pelo outro, a sua relação à historiografia. O conceito central, segundo Hutcheon, é a "presença do passado", muitas vezes realizada sob a forma das narrações históricas paradoxais, cujo traço comum é a tentativa de instituir uma relação dialógica entre o passado e o presente.

$\mathrm{Na}$ metaficção historiográfica, existe uma recusa deliberada de resolver as contradições (HUTCHEON, 1991), desígnio de todas as metanarrativas, e uma permanente tentação paródica que denota a recusa de aceitar as respostas tradicionais às grandes perguntas humanas e a escolha deliberada de uma interrogação permanente que rejeita a certeza tranquilizadora do fato histórico registrado. Em Memorial do Convento, o reinado de D. João V é recriado, nos domínios do espaço físico e sociocultural, juntamente com a guerra de sucessão do trono Espanhol e das perseguições da Santa Inquisição.

O narrador de Memorial do Convento mostra que a história contada nos dias de hoje se dá por aqueles que detinham o poder e traz à tona a saga daqueles nunca antes mencionados na história. $\mathrm{Na}$ guerra, os soldados mortos ou que perderam membros na defesa de seu país são esquecidos. Saramago então, através da personagem Baltazar Sete-sóis, evidencia essa lacuna produzida pelos historiadores. 
Ao narrar a história sob uma ótica diversa da oficial, o narrador desloca o poder para as mãos dos homens comuns, os quais, ainda que obrigados a erigir uma obra com a qual não têm envolvimento algum, são os que detêm o poder de transformação do real. As relações do homem com o trabalho têm um espaço privilegiado em Memorial do Convento. A corrupção da Igreja como instituição, a Lisboa suja, física e moralmente, revelam-se como a imagem real de uma sociedade e de uma época em que a história oficial vê, ou melhor, retrata, sob uma ótica diferente.

Vemos então que Memorial do Convento distingue-se muito do relato meramente histórico. O passado aqui não é evocado para contemplação da magnitude de uma época, antes é evocado para reavaliação crítica, para que enxerguemos como chegamos aos dias atuais e o porquê de tantas mazelas enfrentadas hoje. A elucidação é o que pretende o autor de Memorial do Convento. Aqui nos ativemos à investigação do caráter metaficcional e historiográfico da obra, mas esta constitui um rico objeto de pesquisa em que podem ser levantadas muitas outras leituras, tais como: o papel da mulher e as relações do trabalho, entre outras pesquisas provenientes de outras ciências como a investigação linguística. Sendo assim, diante dos elementos levantados neste trabalho sobre as questões inerentes a pós-modernidade, aos romances histórico e metaficcional, Memorial do Convento, indiscutivelmente se inscreve na literatura como Metaficção Historiográfica.

\section{CONCLUSÃO}

É patente na metaficção historiográfica o papel ativo que é atribuído ao leitor na produção do sentido. Entre o horizonte da história "real" que o leitor conhece através dos vários dispositivos culturais e a história possível que a ficção lhe apresenta abre-se um espaço de liberdade para que o leitor faça sua escolha ideológica e seja capaz de modelar ou remodelar os sistemas simbólicos a que está submetido. Como leitor de ficção ou de história, o consumidor deve se tornar consciente da impossibilidade de nós alguma vez podermos conhecer o passado como referente, já que este é discurso.

José Saramago cumpre com seu papel de nos despertar para o mundo provendo-nos do puro deleite e prazer proporcionado pelo texto. Paralelamente à história de um rei sem escrúpulos e franciscanos ardilosos, existe também a história magnífica de um amor longe da banalidade servil entre as criaturas. Paralela também, aos sonhos de um rei de imortalizar-se por meio de uma obra monumental, um convento gigantesco e arraigado ao chão, está a leveza do sonho de um louco que queria voar numa passarola, de um músico que tocava um cravo magnífico, de um povo pobre e sem trabalho que se submetia a esforços sobre-humanos para erguer as paredes de um monumento nascido da ignomínia dos corações que perderam a razão para viver. 
Essa rainha católica e seu cobertor de penas, seus sonhos libidinosos, seus filhos; esse rei pequeno e imbecil, que imaginava poder construir uma basílica como a de São Pedro para constar na História do mundo, jamais abandonarão nossa memória, pelo que significam do superficial e infeliz que, às vezes, a natureza humana guarda. Além disso, aquele soldado maneta e aquela vidente desgrenhada são os símbolos mais claros da natureza humana: fortes e delicados, sinceros, embora rudes. Eles são o que sonhamos: o Bem e a Liberdade, a sabedoria de existir belamente e sem preconceitos.

\section{REFERÊNCIAS:}

ABDALA Jr., Benjamim. PASCHOALIN, Maria Aparecida. História Social da Literatura Portuguesa. São Paulo: Ática, 1982.

BARTHES, Roland. Aula. São Paulo: Cultrix, 1978.

HUTCHeON, Linda. Poética do Pós-Modernismo: História, Teoria e Ficção. Rio de Janeiro: Imago. 1991.

JAMESON, Frederic. O romance histórico ainda é possível? Revista Novos estudos, CEBRAP, n 77, 2007, p. 185-203.

MAIA, João Roberto. Memorial do convento: "falar das mãos, falar das obras." Revista Alea, v. 6, n. 1, 2004, pp. 117-138.

PERRONE-MOISÉS, Leyla. Formas e usos da negação na ficção histórica de Jose Saramago. In: CARVALHAL, Tânia F. TUTIKIAN, Jane (orgs.). Literatura e História: três vozes de expressão portuguesa. Porto Alegre: Ed. Universidade / UFRFS, 1999.

ROANI, Gerson Luiz. No Limiar do Texto: Literatura e História em José Saramago. São Paulo: Annablume, 2002.

SARAIVA, António José. Iniciação à Literatura Portuguesa. São Paulo: Companhia das Letras, 1999.

SARAIVA, José Hermano. História concisa de Portugal. Publicações Europa-América, 1996.

SARAMAGO, José. Memorial do Convento. 31 ${ }^{\mathrm{a}}$ ed. São Paulo: Bertrand Brasil, 2005. 